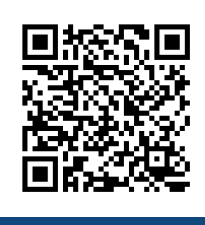

Keywords:

African mahogany

Irradiance

Plant production

Nursery

Received 22/10/2018

Accepted $21 / 1 / / 2018$

Correspondence: goncalvesds@hotmail.com
Mayanne Alves Pereiraa ${ }^{\text {la }}$, Douglas Santos Gonçalves ${ }^{2 a+}$, Patrícia Aparecida de Souza ${ }^{3}$, Filipe Rezende Lucena ${ }^{4}$, Rubens Ribeiro da Silva ${ }^{\mathrm{lb}}$, Gilvano Ebling Brondani ${ }^{2 b}$

\section{LUMINOSITY LEVELS AFFECT THE INITIAL SEEDLINGS GROWTH AND NUTRIENT ACCUMULATION IN Khaya senegalensis A. JUSS}

PEREIRA, M. A.; GONÇALVES, D. S.; SOUZA, P. A.; LUCENA, F. R.; SILVA, R. R.; BRONDANI, G. E. Luminosity levels affect the initial seedlings growth and nutrient accumulation in Khaya senegalensis A. Juss. CERNE, v. 24, n. 4, p. 344-35I, 2018.

\section{HIGHLIGHTS}

Luminosity levels promoted different results in Khaya senegalensis seedlings development.

Plants in full sun accumulated less biomass than in partial luminosity levels.

The nitrogen and magnesium contents changed according to the luminosity.

Low interactions of foliar nutrient and luminosity levels in plant development were found.

\section{ABSTRACT}

Khaya senegalensis, is a promising species for forest production, as it has excellent timber properties and adapts well to local edaphoclimatic conditions. To achieve better results in plant production and growth, some factors are important, such as nutrients, water and light. Light interferes directly with photosynthesis, plant growth and biomass. This study aims to investigate the morphological response and nutrient accumulation in seedlings of Khaya senegalensis under luminosity levels. An experiment was installed in the forest nursery during 150 days. The seedlings were distributed in a completely randomized design with five treatments in luminosity levels (full sun, $70 \%, 50 \%, 30 \%$ and natural shade), and 16 replicates. Height and diameter were measured in 30 days intervals. At the end of the experiment, mass weights (leaf, stem, root and total) were measured, and the root-shoot ratio and seed quality index proposed by Dickson were calculated. The accumulated macro and micronutrient contents were determined from the dry leaf material. The highest plants, diameters and total dry matter were found at levels of $70 \%, 50 \%, 30 \%$, respectively. Plants exposed to natural shade grew less, in relation to plants with higher luminosity levels. As for nutrient accumulation, plants under natural shade accumulated higher levels of iron, while plants in the full sun accumulated more nitrogen contents. Plants with partial light conditions (70\%, 50\%, and 30\%) were heavier in total biomass. Thus, the initial growth of Khaya senegalensis in low light conditions is compromised, whereas partial luminosities favor the growth and quality of seedlings.
I Federal University of Tocantins, Tocantis, Brazil - ORCID: 0000-0003-00 I2-732Xa, 0000-0003-379|-2014 2 Federal University of Lavras, Lavras, Minas Gerais, Brazil - ORCID: 0000-0003-2580-8463a, 0000-000I-8640$5719^{\mathrm{b}}$

${ }^{3}$ Federal University of São João Del Rei, São João Del Rei, Minas Gerais, Brazil - ORCID: 0000-000 I-8249-0944

${ }^{4}$ State University of Maranhão, Maranhão, Brazil - ORCID: 0000-0002-5308-6288 


\section{INTRODUCTION}

Forestry sector has demonstrated global participation in sustainable production, contributing to the reduction of greenhouse gases, as a measure adopted among countries to mitigate the impact on climate change. Forest products industry is globally focused on greenhouse gas removal, carbon footprint and carbon storage (Angelo et al., 2017; Silva and Dias, 2016). Planted forests offer timber and non-timber products for corporate investors and small producers seeking commercial or subsistence purposes, decreasing the use of natural forests (Coelho Junior et al., 2013).

Forests provide social and environmental services, rehabilitating degraded areas, combating the loss of land use capacity and mitigating landscapes (Honda and Durigan, 20I7; Rosa et al., 20I4). Therefore, it is necessary to improve seedling quality production techniques (Bortolini et al., 2012; Navroski et al., 2016).

Plant's biomass production is considered a very important aspect since it requires the interaction of factors such as light, water, carbon dioxide and the continuous flow of mineral salts for its proper development (Souza et al., 2017). The intensity, duration and interval of luminosity on plants influence its development, directly interfering in photosynthesis (Péllico Netto et al., 2015; Taiz and Zeiger, 2013). Photosynthesis is the transformation of light energy into chemical energy, to supply carbohydrates required in plant metabolism (Marenco et al., 20l4).

Light conditions in the environment directly reflect on the adaptive ability and growth of plants (Costa et al., 20I5). Light is fundamental to the initial stage of seedling growth in forest nurseries, and management is important according to the physiological needs of each species of interest. Studies associated with availability and light intensity aiming at a quality production are of extreme importance for development in forest-based activity, conservation, and reforestation programs (Albuquerque et al., 20I5).

To be efficient in forest productivity, it is fundamental to identify responses that promote or maintain plant growth and development in time considering different environmental conditions (Schumacher et al., 20I I; Silva et al., 2017).

African mahogany is one species that has shown good results in forest plantations in Brazil. Mainly rural producers, aiming at long-term investments, are planting it. African mahogany is a genus Khaya specie, belonging to the Meliaceae family, which was introduced in Brazil in silvicultural systems aiming to replace Brazilian mahogany
(Swietenia macrophylla) because it is resistant to the pointer drill (Hypsipyla grandella), representing technical and economic advantage of this species (Barbosa Filho et al., 2016; Barbosa Filho et al., 2018; Casaroli et al., 2018; Corcioli et al., 2016; Santos et al., 2018). Khaya senegalensis $\mathrm{A}$. Juss can live through prolonged droughts (four to six months per year), an advantage in relation to other Khaya species (Bandara et al., 2018; Silva et al., 2016) and a very important factor for several regions in the country, such as in Tocantins state, Brazil.

Khaya senegalensis is classified as a heliophile, semi-deciduous, tolerant to moderate shade. In good soils, such as dense forest wetlands, it can reach 15 to 30 meters in height. Its wood is highly valued and used for quality furniture production (França et al., 20I5).

Previous studies with Khaya senegalensis are indispensable to know the different environmental conditions for crops, especially regarding luminosity, in order to guarantee efficiency and gain in productivity. This study's objective was to evaluate the growth and nutrient accumulation in the biomass of Khaya senegalensis under different luminosity levels.

\section{MATERIAL AND METHODS}

The study was carried out from November 2015 to May 2016, in the experimental area of the Forest Nursery of the Federal University of Tocantins (UFT), Gurupi Campus. The university is located in the southern region of Tocantins State, at $280 \mathrm{~m}$ altitude, $1 \mathrm{I}^{\circ} 43^{\prime} 45^{\prime \prime}$ latitude and 49 $04^{\prime} 07^{\prime \prime}$ longitude. According to Köppen's climatic classification Aw, the regional climate is of humid type with moderate water deficiency (Kriticos et al., 2012). Minimum temperature of $18^{\circ} \mathrm{C}$ and maximum temperature of $35^{\circ} \mathrm{C}$, with average annual rainfall of $1,500 \mathrm{~mm}$.

Khaya senegalensis seeds used for production were purchased from private companies and imported from Burkina Faso, West Africa. The seeds were placed directly in beds containing washed sand, located in an area with a black polyethylene screen at $50 \%$ shading and kept under daily irrigation.

After germinating with at least a pair of leaves, the seedlings were transplanted into $20 \times 30 \mathrm{~cm}$ polyethylene bags containing approximately 3.8 liters of substrate composed of $20-30 \mathrm{~cm}$ of subsoil layer of Mediumtextured Yellow Red Latosol (Embrapa, 1999), charred rice husk, washed sand and commercial substrate, in a ratio of 2:I:I:I (v/v), respectively. Chemical and physical analyses were carried out (Table I). After 90 days of experiment, supplemental fertilization with $35 \mathrm{mg} \cdot \mathrm{dm}^{-3}$ of potassium chloride, $53 \mathrm{mg} \cdot \mathrm{dm}^{-3}$ of ammonium sulphate and $0.5 \mathrm{mg}$.

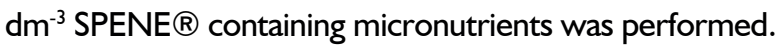


TABLE I Chemical and physical characteristics of the substrate used for seedling production of Khaya senegalensis.

\begin{tabular}{|c|c|c|c|c|c|c|c|c|c|c|c|c|c|c|}
\hline $\mathrm{pH} \mathrm{CaCl}{ }_{2}$ & $\mathrm{H}+\mathrm{Al}$ & $\mathrm{Al}$ & $\mathrm{Ca}$ & $\mathrm{Mg}$ & $\mathrm{T}$ & $\mathrm{t}$ & SB & $\mathrm{K}$ & $\mathrm{P}$ & $\mathrm{Fe}$ & $\mathrm{Cu}$ & $\mathrm{Mn}$ & $\mathrm{Zn}$ & B \\
\hline & \multicolumn{7}{|c|}{ 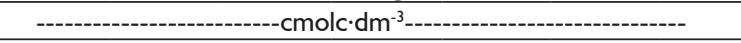 } & \multicolumn{7}{|c|}{ 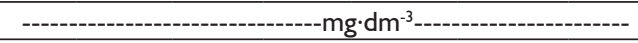 } \\
\hline 5.6 & 2.00 & 0 & 3.1 & 1.2 & 6.75 & 4.75 & 4.75 & 175 & 398.7 & 15 & 0.3 & 4.4 & 1.1 & 0.1 \\
\hline O.M & O.C. & $\mathrm{V}$ & & Clay & Silt & Sand & & & & & & & & \\
\hline \multicolumn{3}{|c|}{----------\%------- } & & \multicolumn{4}{|c|}{-------g'kg-1------ } & & & & & & & \\
\hline $1.9 \%$ & I.I & 70 & & 185 & 50 & 465 & & & & & & & & \\
\hline
\end{tabular}

T: Cation exchange capacity; t: Effective cation exchange capacity; SB: sum of the bases; O.M: organic matter; O.C: organic carbon e V: saturation bases.

Fifty days after emergence, African mahogany seedlings were selected according to the number of leaves, height and phytosanity avoiding heterogeneity. The experiment was conducted in a completely randomized design, with five treatments and 16 replicates. The seedlings were distributed in different luminosity levels, where: $100 \%$ (full sun), $70 \%, 50 \%, 30 \%$ (by use of shady mesh) and natural shade.

The seedlings in natural shade were placed under a remnant native vegetation area of Cerrado stricto sensu in the Gurupi University campus. Other levels of luminosity were obtained with black nylon screens (shady mesh) of wood and steel wires located in the UFT Forest Nursery. During the treatment plants the seedlings were allocated equidistant at 0.25 meters and irrigation was done twice a day.

Luminosity levels for each environment was determined based on mean values obtained from 10 spots. These values were recorded between II:00 a.m. and I:00 p.m., without clouds, using a LX-IOIOBS digital luxmeter, Brand Lux Tester. Measurements were converted from lux to $\mu \mathrm{mol}$ photons $\mathrm{m}^{-2} \cdot \mathrm{s}^{-1}$ (Table 2).

TABLE 2 Luminosity levels percentages for treatments with Khaya senegalensis.

\begin{tabular}{cc}
\hline Treatments & *Luminosity $\left(\mu\right.$ mol photons $\left.\mathrm{m}^{-2} \cdot \mathrm{s}^{-1}\right)$ \\
\hline Full sun $(\mathrm{I} 00 \%)$ & $2.089 \pm 74$ \\
$70 \%$ luminosity & $1.462 \pm 63$ \\
\cline { 2 - 2 } $50 \%$ luminosity & $1.044 \pm 47$ \\
$30 \%$ luminosity & $626 \pm 65$ \\
Natural shade $(1 \%)$ & $27 \pm 5$ \\
\hline
\end{tabular}

*Mean and standard deviation.

Morphological measurements were performed throughout the 150-day experiment, at a 30-day interval. Plant height $(\mathrm{PH})$ was measured with a ruler graduated in $\mathrm{cm}$, positioning it at the stem insertion and measuring to the apical meristem; collection diameter (CD), obtained at $0.5 \mathrm{~cm}$ from stem insertion, using a digital caliper with reading in $\mathrm{mm}$.

At the end of the experiment, the substrate was removed by cleaning the root system with water under low pressure, subdivided into parts (i.e., leaves, stem and root). To determine dry biomass, the plants underwent an oven drying process with forced air circulation, at $65^{\circ} \mathrm{C}$ for 72 hours, until a constant mass was obtained (Gomes and Paiva, 20I I). Once dried, the biomass was weighed in an electronic analytical balance $(0.000 \mathrm{lg})$. Leaf, stem, root dry mass, and its total were obtained.

Based on data gathered, the Dickson Quality Index (DQI) was calculated with the following equation I (Dickson et al., 1960), Where: DQI -Dickson Quality Index; TDM -total dry mass (g); $\mathrm{PH}$-plant height (cm); $\mathrm{CD}$ - collection diameter $(\mathrm{mm})$; APDM-aerial part dry mass (g); MSR-root dry mass (g).

After biomass determinations, the leaf material was dried and ground for quantification of the macro and micronutrient contents, according to the methodology described by Malavolta et al. (1997). Total nitrogen was determined by titration after digestion with sulfuric acid. Phosphorus levels were determined in samples submitted to nitroperchloric digestion and evaluated by visible spectrophotometry. The same sample was analyzed for content of other nutrients $(\mathrm{Ca}, \mathrm{Mg}, \mathrm{K}, \mathrm{Fe}$, $\mathrm{Zn}$ and $\mathrm{Mn}$ ) by atomic absorption spectrometry.

Data was tested to normality, and then subjected to variance analysis (ANOVA). When significant effects were found on the $F$ test, regression was used to adjust models based on the significance of coefficients at I and $5 \%$ of probability. All analyses were processed using Assistat 7.7 software, and regression graphs were plotted using the statistical program SigmaPlot version 10.0. Maximum brightness points were determined from the regression derivative of the equations.

\section{RESULTS AND DISCUSSION}

Luminosity levels promoted different results in Khaya senegalensis seedlings development. Growth in height was greater when there was $70 \%, 50 \%$ and $30 \%$ luminosity averaging 54.55, 53.39, and $51.59 \mathrm{~cm}$, respectively at measurement performed on the $150^{\text {th }}$ day (Figure I). Plant height analyzed as a function of time showed similar responses for all treatments with increasing linear adjustments, greater in the partial luminosity levels $(70 \%, 50 \%$ and $30 \%)$. Plants in full sun $\left(\beta_{1}=0.2184\right)$ and natural shade $\left(\beta_{1}=0.0647\right)$ showed the smallest increments. This growth increase through internodes elongation is a common reaction in plants subjected to irradiance levels, characterizing a morphological response of a species to tolerate given environmental conditions (Taiz and Zeiger, 20I3). 


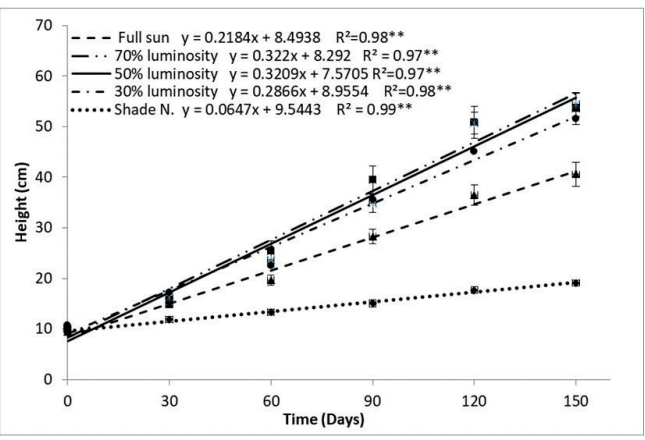

FIGURE I Growth in height (cm) of Khaya senegalensis at different levels of luminosity as a time function.

The plants in a natural shade showed significant differences to other treatments at 30 days, but at 90 days, plants under full sun differed from those in partial luminosity treatments (70\%, $50 \%$ and $30 \%)$, demonstrating the need for light in the range of 1,500 (70\%), I,000 (50\%), to $600(30 \%) \mu \mathrm{mol}$ photons $\mathrm{m}^{-2} \cdot \mathrm{s}^{-1}$ for further development. Roweder et al. (20I5) achieved the highest results in treatments tested in Swietenia macrophylla, with $18.04 \mathrm{~cm}$.

Collection diameter response of the Khaya senegalensis species was similar to that of plant height in this study, with increasing linear responses over time. However, significant differences between treatments were verified at 120 days between full sun and $30 \%$, $50 \%$ and $70 \%$ luminosity levels (Figure 2). Statistical differences observed in sample values were significant by day 150 , with $4.72 \mathrm{~mm}$ of plants under natural shade, and $17.3 \mathrm{I} \mathrm{mm}$ of plants exposed to $70 \%$ of luminosity. This represented an increase in diameter and mass accumulation in the basal part of the plant that sustains the shoot for quality growth.

Natural shade or low luminosity plants had diameter values of $\beta_{1}=0.0162$ in polynomial equations (equivalent to $4.72 \mathrm{~mm}$ ), lower results than plants kept in other treatments, evidencing that less luminosity than $30 \%$

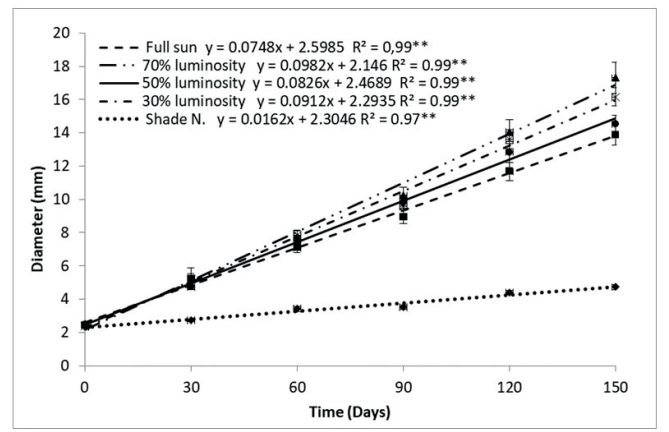

FIGURE 2 Growth in diameter ( $\mathrm{mm}$ ) of young plants of Khaya senegalensis at different levels of luminosity as a time function. compromises optimal development (Figure 2). Increases in diameter of $\beta_{1}=0.0826$, equivalent to $15.81 \mathrm{~mm}$, were found for $70 \%, 50 \%$ and $30 \%$ luminosity condition. With $50 \%$ luminosity and a complete nutrient solution for Khaya ivorensis and Khaya senegalensis, Alves (2013) obtained diameter increases of $\beta_{1}=0.0174(9.5 \mathrm{~mm})$ and $\beta_{1}=0.0538 \mathrm{I}(8 \mathrm{~mm})$ each in 150 reviews. Moura (2015) found an average diameter of $8 \mathrm{~mm}\left(\beta_{1}=0.5515\right)$ for Khaya senegalensis under $50 \%$ luminosity and with additional NPK doses, lower values than those found in this study.

Both diameter and height growth for Khaya senegalensis did not show significant differences between partial luminosity levels throughout the experiment. Therefore, the species develops better under these conditions. França et al. (2015) and Santos et al. (2018) reports that Khaya senegalensis moderately tolerates shade in the initial phase. This response is typical of secondary species, which develop better on partial light levels. Some species of the secondary group are heliophilous, e.g. Khaya senegalensis, characterized by species that establish and grow under canopy, but require clearings for growth and reproduction (Sccoti et al., 20I I).

Biomass production of Khaya senegalensis as a function of luminosity levels had significant results ( $p$ $\leq 0.05$ ) and adjustments with quadratic polynomial functions (Figure 3). A decrease in vegetal biomass accumulation was observed, with increased luminosity of $42.75 \mathrm{~g}$ in plants under full sun. Higher results were $65.57,63.55$ and $68.92 \mathrm{~g}$ for $70 \%, 50 \%$ and $30 \%$ respectively, reaffirming that the species needs an adequate amount of light for its initial development. The lowest average of total dry mass was in natural shade plants $(3.79 \mathrm{~g})$, since they accumulated little biomass, due to the low irradiance. It jeopardizes the functioning of the photosynthetic process and its development.

The maximum point in luminosity curves for biomass accumulation was 58\%, 62\%, 58\% and 59\% light, for the respective foliar, stem, root and total biomasses. Therefore, ideal luminosity levels for Khaya

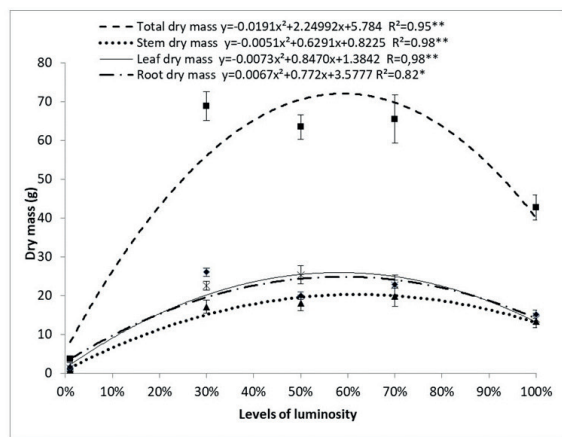

FIGURE 3 Total dry mass, stem dry mass, leaf dry mass, and root dry mass of Khaya senegalensis according to the different levels of luminosity. 
senegalensis development is around $60 \%$ (Figure 3). To achieve this accumulation of biomass in the plant, light, as well as other abiotic factors, along with the genetic material interact in plant growth. Benincasa (2003) states that a plant only grows when the production of photoassimilates supplies the metabolic demand, storing a portion for energy and investing the rest in biomass growth. Plants in shaded or low-luminosity environments may have low photosynthetic activity, not enough to supply adequate demand for metabolic activities, to invest in growth and to accumulate biomass in the plant.

Plants in full sun accumulated less biomass when compared to partial luminosity levels. It is probable that their transpiratory rate was higher, however, energy expenditure was also higher and compromised biomass accumulation. Franck and Vaast (2009) consider that some early forest species under full sun conditions reduce carbon assimilation due to the decrease in stomatal conductance and temperature increase, consequently, lower growth and accumulation of masses.

Considering the Dickson Quality Index (DQI), an increase in luminosity level promoted a quadratic response, with a maximum point at $59 \%$ luminosity (Figure 4). The highest seed quality indexes at 150 days were found in partial luminosity levels of $70 \%$ and $30 \%$, with 13.93 and 14.95 each. Under $50 \%$ luminosity and full sun, the indices were 10.12 and 8.95 each. This index serves as a morphological quality indicator of plants that could be planted in the field. These high indices occurred because seedlings had advanced formation and high biomass. Alves (2013) worked with complete nutrient solution in the species Khaya senegalensis under $50 \%$ luminosity and found a 6.75 index.

Plants under low luminosity conditions (natural shade) had a DQI of 0.69 , higher than the standard proposed by Gomes and Paiva (20II), who establish indexes higher than 0.20 for seedlings, due to its robustness and equilibrium in biomass distribution (Figure 4). However, even seedlings with large DQI,

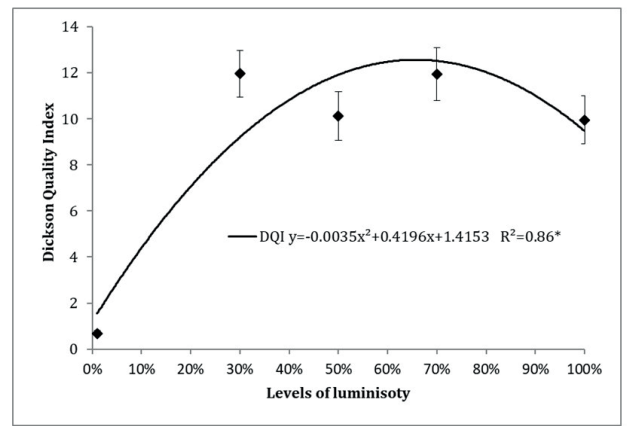

FIGURE 4 Dickson quality index (DQI) of the Khaya senegalensis as a function of the luminosity levels. suitable for planting in the field, leaves that grow in very shady environments, may undergo photoinhibition, or even, photooxidation when exposed to high irradiance. These physiological phenomena vary from species to species, plant stage and edaphoclimatic conditions, which point to the acclimatization capacity and the phenotypic plasticity of the species (Taiz and Zeiger, 20l3).

For the foliar nutrient accumulation indicators of this study, there were significant effects ( $p \leq 0.05$ ) in most of the results found, and some were found for nutritional contents in species of the genus Khaya, which includes some studies that mention results with leaf nutrient extraction (Table 3).

TABLE 3 Nutritional contents found in leaves of species of the genus Khaya in different luminosity conditions.

\begin{tabular}{|c|c|c|c|c|c|c|c|c|c|}
\hline \multirow{2}{*}{$\begin{array}{c}\text { Scientific } \\
\text { papers } \\
\text { (Author and } \\
\text { specie) }\end{array}$} & \multirow{2}{*}{$\begin{array}{c}\text { Luminosity } \\
\text { levels }\end{array}$} & \multicolumn{8}{|c|}{ Nutritional contents $\left(\mathrm{g} \cdot \mathrm{kg}^{-1}\right)$} \\
\hline & & $\mathrm{N}$ & $\mathrm{P}$ & $\mathrm{K}$ & $\mathrm{Mg}$ & $\mathrm{Ca}$ & $\mathrm{Fe}$ & Mn & $\mathrm{Zn}$ \\
\hline Moura & & & & & & & & & \\
\hline $\begin{array}{c}(2015) \\
\text { Khaya } \\
\text { senegalensis }\end{array}$ & $\begin{array}{l}50 \\
(\%) \\
\end{array}$ & 16 & 2 & 23 & 2 & 12 & - & - & - \\
\hline $\begin{array}{c}\text { Alves } \\
(2013)\end{array}$ & & & & & & & & & \\
\hline $\begin{array}{c}\text { Khaya } \\
\text { senegalensis }\end{array}$ & $\begin{array}{c}50 \\
(\%)\end{array}$ & 29 & 3 & 15 & 3 & 15 & - & - & - \\
\hline $\begin{array}{l}\text { Corcioli } \\
(2016)\end{array}$ & & & & & & & & & \\
\hline $\begin{array}{c}\text { Khaya } \\
\text { ivorensis }\end{array}$ & Full sun & 32 & I & 8 & 2 & 12 & 521 & 50 & 15 \\
\hline
\end{tabular}

Where: $\mathrm{N}=$ Nitrogen; $\mathrm{P}=$ Phosphorus; $\mathrm{K}=$ Potassium; $\mathrm{Mg}=$ Magnesium; $\mathrm{Ca}=$ Calcium; $\mathrm{Fe}=$ Iron; $\mathrm{Mn}=$ Manganese and $\mathrm{Zn}=$ Zinc.

There was a significant effect $(p \leq 0.05)$ on the $F$ test regarding the accumulation of leaf macronutrients, with adjustments in quadratic functions for phosphorus, potassium and calcium (Figure 5). Adjustments for nitrogen and magnesium contents were linear, increasing and decreasing respectively, with the increase of luminosity. From the maximum point found in plant biomass (Figure 3), it is verified that $60 \%$ luminosity is ideal controlled seedlings production, whereas $50 \%$ luminosity show the largest macronutrient contents in the seedlings in the following decreasing order: nitrogen, calcium, potassium, phosphorus and magnesium.

Results obtained for nutritional indicators in

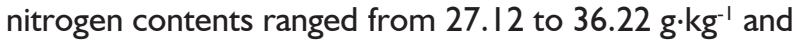
had higher contents with increasing luminosity (Figure $5)$. Elevated nitrogen content in plants under full sun may have occurred because their leaves are thicker, allowing a great amount of nitrogen per unit of leaf area. Meanwhile, the leaves of shaded plants were thinner and had lower nitrogen contents per unit area. Nitrogen acts 


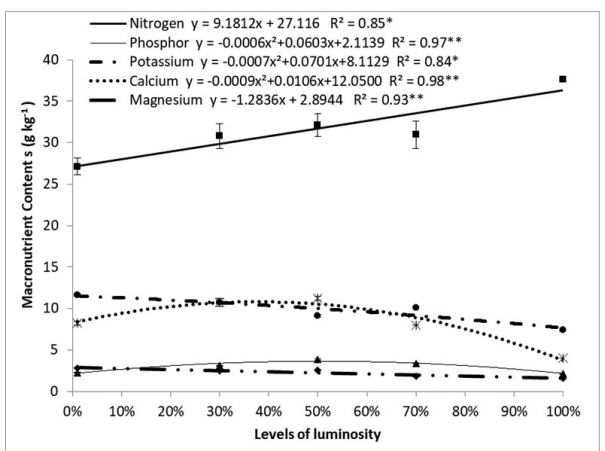

FIGURE 5 Leaf macronutrient contents of Khaya senegalensis as a function of luminosity levels.

on the differentiation and stabilization of the chloroplast structure in the photochemical phase of photosynthesis (Taiz and Zeiger, 2013). Corcioli (2016), studying Khaya ivorensis leaves, found foliar nitrogen contents of 32.60 $\mathrm{g} \cdot \mathrm{kg}^{-1}$ in plants exposed to full sun, and Moura (2015), in a study with NPK doses, observed levels of $19 \mathrm{~g}^{\mathrm{kg}} \mathrm{g}^{-1}$ in Khaya senegalensis under $50 \%$ luminosity.

Accumulated phosphorus and potassium contents showed significant effects for luminosity levels, with responses in quadratic functions in the regression analysis, reaching a maximum point of $50 \%$ luminosity. Phosphorus levels for partial luminosity levels were higher (Figure 5), compared to what Malavolta et al. (1997) establish, from 1.0 to $2.3 \mathrm{~g}^{\mathrm{kg}} \mathrm{gg}^{-1}$, and with significant difference between full sun and $50 \%$ luminosity. Phosphorus is one of the components of nucleic acids, phosphate sugars, which acts in the structure and stabilization in the photosynthetic process, in ATP, in electron transport and phosphorylation, also in $\mathrm{CO}_{2}$ fixation and Calvin cycle, in assimilates transport, and starch synthesis. Phosphate deficiency results in an assimilated accumulation in the chloroplast, reducing photosynthesis (Taiz and Zeiger, 2013).

Potassium content was lower than that indicated for crop in all treatments, except for $70 \%$ luminosity levels, with a content of $11.12 \mathrm{~g} \cdot \mathrm{kg}^{-1}$ (Figure 5). This element acts on the regulation of the stomatal movement, directly inferring $\mathrm{CO}_{2}$ assimilation and transpiratory rate of the plant. Corcioli (2016) found $8 \mathrm{~g} \cdot \mathrm{kg}^{-1}$ in Khaya

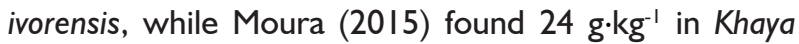
senegalensis seedlings.

Analysis showed significant effects on the $F$ test for calcium and magnesium contents. Generally, the requirements of some of the major micronutrients for plants are in the following decreasing order: $\mathrm{Fe}>\mathrm{Mn}>$ $\mathrm{Zn}>\mathrm{B}>\mathrm{Cu} .50 \%$ luminosity is suggested as ideal for Khaya senegalensis, since the accumulation of foliar micronutrients in this study obeyed this decreasing order: $\mathrm{Fe}>\mathrm{Mn}>\mathrm{Zn}$ (Figure 6).

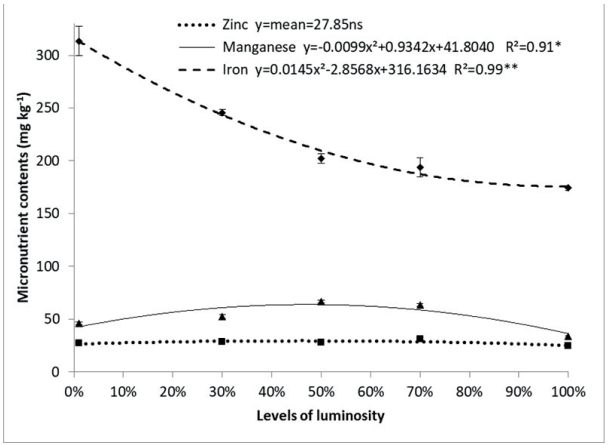

FIGURE 6 Leaf micronutrient contents of Khaya senegalensis as a function of light levels.

Manganese contents showed significant differences in luminosity treatments and quadratic responses with a maximum point of $48 \%$ light in the curve (Figure 6). Results ranged from 34.0I to $66.75 \mathrm{mg} \cdot \mathrm{kg}^{-1}$. Manganese acts in photosynthesis with participation in enzymatic and cofactor components, in photosynthesis reaction in water photolysis, releasing the oxygen to form ATP and NAPH for subsequent $\mathrm{CO}_{2}$ fixation (Taiz and Zeiger, 20l3).

Zinc contents did not show significant effects in treatments with values between 24.50 and $31.01 \mathrm{mg} \cdot \mathrm{kg}^{-1}$ (Figure 6). These results were higher than those found by Corcioli (2013), with Khaya ivorensis, which were of $15.40 \mathrm{mg} \cdot \mathrm{kg}^{-1}$ in complete nutrient solution. Zinc is a fundamental micronutrient, and lacking it often promotes crop deficiency in tropical soils.

Iron contents in low levels of luminosity found in Khaya senegalensis seedlings were higher than other treatments with $313 \mathrm{mg} \cdot \mathrm{kg}^{-1}$, demonstrated in the curve of response with decrease to the increase of luminosity (Figure 6). Corcioli (2016) found high iron contents in Khaya ivorensis with complete nutrient solution under full sun conditions of $521.20 \mathrm{mg} \cdot \mathrm{kg}^{\prime}$.

Interactions of foliar nutrient accumulations and luminosity levels in plant development are scarcely found and demonstrate the particularity of organic and inorganic nutrition functions in photosynthetic activity in forest species. Thus, the importance of nutrients for plant productivity stems from the participation of these elements in structures and vital processes, impacting cell division and stretching, promoting plant growth and development, and requiring further studies to understand these processes.

\section{CONCLUSIONS}

Luminosity levels clearly influence the growth and biomass of Khaya senegalensis plants, where $60 \%$ light exposure and a range between 1.500 and $600 \mu \mathrm{mol}$ 
$\mathrm{m}^{2} \cdot \mathrm{s}^{-1}$ is recommended for a better initial development of the species, allowing more growth. Plant growth is compromised in natural shade conditions or with low light.

The highest levels of nitrogen were found in plants under full sun, while in natural shade higher leaf iron contents were obtained. Nutrients accumulation follows the descending order of $\mathrm{N}>\mathrm{Ca}>\mathrm{K}>\mathrm{P}>\mathrm{Mg}$ and; micronutrients $\mathrm{Fe}>\mathrm{Mn}>\mathrm{Zn}$.

\section{REFERENCES}

ALBUQUERQUE, T.C.S.; EVANGELISTA, T.C.; NETO, AARA Níveis de sombreamento no crescimento de mudas de castanheira do Brasil. Revista Agro@mbiente, v.9, n.4, p. $440-445,2015$.

ALVES, M.S. Produção e qualidade de mudas de mogno africano cultivadas com solução nutritiva. 2013. 63 p. Dissertação de mestrado da Universidade Federal de Roraima, Boa vista.

ANGELO, H; ALMEIDA, A.N.; FONTES, P.J.P.; SOUZA, Á.N. Determinantes para um Sistema de Informação Florestal. Floresta e Ambiente, v.24, p. I-9, 2017.

BANDARA, K.M.A.; ARNOLD, R.J. Seed source variation for growth and stem form in the exotic species Khaya senegalensis in Sri Lanka. New Forests, v.49, n. 4, p.489$510,2018$.

BARBOSA FILHO, J.; CARVALHO, M.A.; OLIVEIRA, L.S.; KONZEN, E.R.; BRONDANI, G.E. Mini-cutting technique for Khaya anthotheca: selection of suitable IBA concentration and nutrient solution for its vegetative propagation. Journal of Forestry Research, v.21, n. I, p.73-84, 2018.

BARBOSA FILHO, J.; CARVALHO, M.A.; OLIVEIRA, L.S.; KONZEN, E.R.; CAMPOS, W.F.; BRONDANI, G.E. Propagation of Khaya anthotheca: interspecific grafting with Swietenia macrophylla and air layering. Cerne, v.22, n.4, p.475-484, 2016.

BENINCASA, M.M.P. Análise de crescimento de plantas: noções básicas. FUNEP, 2003. 42 p.

BORTOLINI, M.F; KOEHLER, H.S.; ZUFFELLATO-RIBAS, K.C.; FORTES, A.M.T. Crescimento de mudas de Gleditschia amorphoides Taub. produzidas em diferentes substratos. Ciência Florestal, v.22, n. I, p. 35-46, 2012.

CASAROLI, D; ROSA, F.O.; ALVES JÚNIOR, J.; EVANGELISTA, A.W.P.; BRITO, B.V.; PENA, D.S. Aptidão edafoclimática para ○ mogno-africano no Brasil. Ciência Florestal, v.28, n.I, p.357-368, 2018

COELHO JUNIOR, L.M.; REZENDE, J.L.P.; OLIVEIRA, A.D. Concentração das exportações mundiais de produtos florestais. Ciência Florestal, v.23, n.4, p.69I-70I, 2013.

CORCIOLI, G.; BORGES, J.D.; JESUS, R.P. Deficiência de macro e micronutrientes em mudas maduras de Khaya ivorensis estudadas em viveiro. Cerne, v.22, n. I, p.I2I-I28, 2016.
COSTA, A.C.; REZENDE-SILVA, S.L.; MEGGUER, C.A.; MOURA, L.M.F; ROSA, M.; SILVA, A.A. The effect of irradiance and water restriction on photosynthesis in Young jatobá-do-cerrado (Hymenaea stignocarpa) plants. Photosynthetica, v.53, n.I, p.II8-I27, 2015.

DICKSON, A.; LEAF, A.L.; HOSNER, J.F. Quality appraisal of white spruce and white pine seedling stock in nurseries. The Forestry Chronicle, v.36, n. I, p. I0-13, 1960.

EMBRAPA. Centro Nacional de Pesquisa de Solos. Sistema Brasileiro de Classificação de Solos. Embrapa Solos, 1999. 412 p.

FRANÇA, T.S.F.A.; ARANTES, M.D.C.; PAES, J.B.; VIDAURRE, G.B.; OLIVEIRA, J.T.S.; BARAÚNA, E.E.P. Características anatômicas e propriedades físico-mecânicas das madeiras de duas espécies de mogno africano. Cerne, v.2I, n.4, p.633640, 2015.

FRANCK, N.; VAAST, P. Limitation of coffee leaf photosynthesis by stomatal conductance and light availability under different shade levels. Trees-struct funct, v.23, n.4, p.76I769, 2009.

GOMES, J.M.; PAIVA, H.N. Viveiros florestais (propagação sexuada), Série didática. Editora UFV, 201 I, I16 p.

HONDA, EA; DURIGAN, G A restauração de ecossistemas e a produção de água. Hoehnea, v.44, n.3, p.3।5-327, 2017.

KRITICOS, D.J.; WEBBER, B.L.; LERICHE, A.; OTA, N.; MACADAM, I.; BATHOLS, J.; SCOTT, J.K. CliMond: global high resolution historical and future scenario climate surfaces for bioclimatic modelling. Methods in Ecology \& Evolution, v.3, p.53-64, 2012.

MALAVOLTA, E.; VITTI, G.C.; OLIVEIRA, S.A. Avaliação do estado nutricional das plantas: Princípios e aplicações. 2.ed. Potafós, 1997. 315 p.

MARENCO, R.A.; ANTEZANA-VERA, S.A.; GOUVÊA, P.R.S; CAMARGO, M.A.B.; OLIVEIRA, M.F; SANTOS, J.K.S. Revista Ceres, v.6I, p.786-799, 2014.

MOURA, T.M. Qualidade de mudas de Khaya senegalensis em função da adubação com macronutrientes. 2015. 40 p. Dissertação de mestrado da Universidade Federal do Tocantins, Gurupi.

NAVROSKI, M.C.; ARAÚJO, M.M.; CUNHA, F.S.; BERGHETTI, Á.L.P.; PEREIRA, M.O. Redução da adubação e melhoria das características do substrato com o uso do hidrogel na produção de mudas de Eucalyptus dunnii Maiden. Ciência Florestal, v.26, n.4, p.II55-II65, 2016.

PÉLLICO NETTO, S.; SANQUETTA, C.R.; CARON, B.O.; BEHLING, A.; SIMON, A.A.; CORTE, A.P.D.; BAMBERG, R. Ground level photosythetically active radiation dynamics in stands of Acacia mearnsii De Wild. Anais da Academia Brasileira de Ciências, v.87, n.3, p. I833-I845, 2015. 
ROSA, F.S.; TONELLO, K.C.; VALENTE, R.O.A.; LOURENCO, R.W. Estrutura da paisagem, relevo e hidrografia de uma microbacia como suporte a um programa de pagamento por serviços ambientais relacionados à água. Revista Ambiente \& Água, v.9, n.3, p.526-539, 2014.

ROWEDER, C.; NASCIMENTO, M.S.; SILVA, J.B. Produção de mudas de mogno sob diferentes substratos e níveis de luminosidade. Journal of Bioenergy and food science, v.2, n.3, p.9I-97, 2015.

SANTOS, F.M.; TERRA, G.; CHAER, G.M.; MONTE, M.A. Modeling the height-diameter relationship and volume of young African mahoganies established in successional agroforestry systems in northeastern Brazil. New forests, v.49, p.I- 19, 2018.

SCCOTI, M.S.V.; ARAUJO, M.M.; WENDLER, C.F.; LONGHI, S.J.Mecanismos de regeneração natural em remanescente de floresta estacional decidual. Ciência Florestal, v.2I, n.3, p.459-472, 201 I.

SCHUMACHER, M.V.; WITSCHORECK, R.; CALIL, FN Biomassa em povoamentos de Eucalyptus spp. de pequenas propriedades rurais em Vera Cruz, RS. Ciência Florestal, v.2I, n.I, p. I7-22, $201 \mathrm{I}$.
SILVA, EP; FERREIRA, PAA; FURTINI-NETO, AE; SOARES, CRFS Micorrizas arbusculares e fosfato no desenvolvimento de mudas de cedro-australiano. Ciência Florestal, v.27, n.4, p. I269-1281, 2017.

SILVA, LF; FERREIRA, GL; SANTOS, ACA; LEITE, HG; SILVA, ML Equações Hipsométricas, Volumétricas e de Crescimento para Khaya ivorensis Plantada em Pirapora. Floresta e Ambiente, v.23, n.3, p.362$368,2016$.

SILVA, OM; DIAS, JMN Evaluation of technological intensity of exports in the forestry sector. Revista Árvore, v.40, n.2, p.297-305, 2016.

SOUZA, CSCR; SANTOS, VAHF; FERREIRA, MJ; GONCALVES, JFC Biomassa, crescimento e respostas ecofisiológicas de plantas jovens de Bertholletia excelsa bonpl. submetidas a diferentes níveis de irradiância. Ciência Florestal, v.27, n.2, p.557-569, 2017.

TAIZ, L; ZEIGER, E Fisiologia vegetal. 5. ed. ArtMed, 20I3. $954 \mathrm{p}$. 